\title{
Anatomy of the Developing Fruit of Metrodorea nigra A. St.- Hil. (Rutaceae)
}

\author{
Luiz Antonio de Souza*, Sônia Maciel da Rosa And Ismar Sebastião Moscheta \\ Departamento de Biologia; Universidade Estadual de Maringá; Av. Colombo, 5790; 87020-900; Maringá - PR - \\ Brasil
}

\begin{abstract}
The pericarp and seed in development of Metrodorea nigra were investigated structurally.The flowers and fruits in different stages of maturation were fixed in FAA 50 and cross- and longitudinally sectioned, according to usual techniques. The differentiated epicarp was represented by the periderm of subepidermal origin. The mesocarp was parenchymatous. The endocarp was sclerenchymatous and originated from the meristematic action of the inner epidermis of the ovary. The seed was endotestal and originated from an anatropous, bitegmic and crassinucellate ovule. The nucellus and the endosperm occurred in small quantity in the mature seed. The embryo was straight with thick cotyledons. The seed and the endocarp were ejected in the autochory process. The fruit was capsular and coccarium.
\end{abstract}

Key words: anatomy, Metrodorea nigra, Rutaceae, fruit, seed

\section{INTRODUCTION}

Rutaceae consists of about 150 genera and 1500 species. It is nearly cosmopolitan in distribution, but mostly tropical and subtropical (Cronquist, 1981). Metrodorea nigra A. St.-Hil. (Rutaceae), popularly known as "carrapateira" or "caputunapreta", is a tree four to five meters high, typical of the sub-canopy of the forests in Paraná State, Brazil. This species is recommended for the densification of the degraded forests in permanent preservation and its wood is used in the civil construction (Lorenzi, 1992).

The fruits of Rutaceae are diverse (Cronquist, 1981). There are several types of the fruits in this family and that of Esenbeckia H.B.K., similar to that of M. nigra, is classified as a coccarium - one derived from a schizocarpous gynoecium (Spjut, 1994). The carpels in the flowers of Rutaceae are not very adherent and become multiple with the development of the fruit (Barroso et al., 1999). Besides the difficulty of classifying certain Rutaceae fruits, the seeds of several species of this family (e.g. M. nigra) are ejected from the mature fruit. The endocarp tissue participates in this autochoric process in several Rutaceae species (Barroso et al., 1999). The dry and lignified endocarp of Esenbeckia febrifuga (St. Hill.) A. Juss. ex Mart. (Beltrati, 1991) and Pilocarpus pennatifolius Lem. (Souza et al., 2005) also participate in the ejection of the seeds of its fruit. Several works on the anatomy of Rutaceae seeds did not mention Metrodorea (Boesewinkel, 1977; Boesewinkel, 1978; Boesewinkel and Bouman,

\footnotetext{
Author for correspondence
} 
1978; Corner, 1976; Beltrati, 1991; Souza et al., 2005).

Anatomical analysis of the fruit and the seed in development of $M$. nigra was the objective of this work. Its purpose was to aid in the correct classification of the fruit, elucidate the origin of the tissue involved in the ejection of the seed and enlarge the knowledge on the structure of the fruit and the seed in Rutaceae.

\section{MATERIALS AND METHODS}

The "Dr. Luiz Teixeira Mendes Horto Florestal" is a 37 ha forest remnant located in the city of Maringá, Paraná State, Brazil between the meridians $51^{\circ} 30^{\circ}$ and $54^{\circ} \mathrm{W}$ and the parallels $22^{\circ}$ $30^{\prime}$ and $24^{\circ} 30 \mathrm{~S}$, with an average altitude of 556 meters. The flowers and young and mature fruits of two $M$. nigra specimens were collected in this area, fixed in formalin-acetic acid-ethyl alcohol (FAA), and then preserved in $70 \%$ ethanol. The material was dehydrated using an ethyl alcohol/xylol series, and the flowers and fruits were embedded in paraffin wax (Johansen, 1940). Twelve (12) $\mu \mathrm{m}$ sections (cross- and longitudinal) were cut, mounted serially, and stained with the safranin and hematoxylin (Johansen, 1940; Dnyansagar, 1958). Freehand sections were also made and colored with the astral blue safranin. Specific color tests for the cellulose (chloriodide of zinc test), lignin (phloroglucin test), tannin (ferric sulfate reaction), lipids (sudan III test) and mucilage (thionine and methylene blue test) were carried out according to methodology described in the literature (Johansen, 1940; Berlyn and Miksche, 1976). The cellular form of the pericarp was analyzed using the Jeffrey maceration process (Johansen, 1940). The vouchers of the studied species were deposited in the Herbarium of Universidade Estadual de Maringá (HUEM): BRASIL. Paraná. Maringá, Horto Florestal Dr. Luiz Teixeira Mendes, 13-XII-1999 (fl), Mourão 5486, 5487 (HUEM).

\section{RESULTS}

\section{Fruit development}

The flowers occurred in the axillary or terminal thyrsoid inflorescences and in the stem regions without the leaves. The short axes were usually undivided; when divided, three flowers were present (Fig. 1). One or two (rarely more) fruits developed per inflorescence.

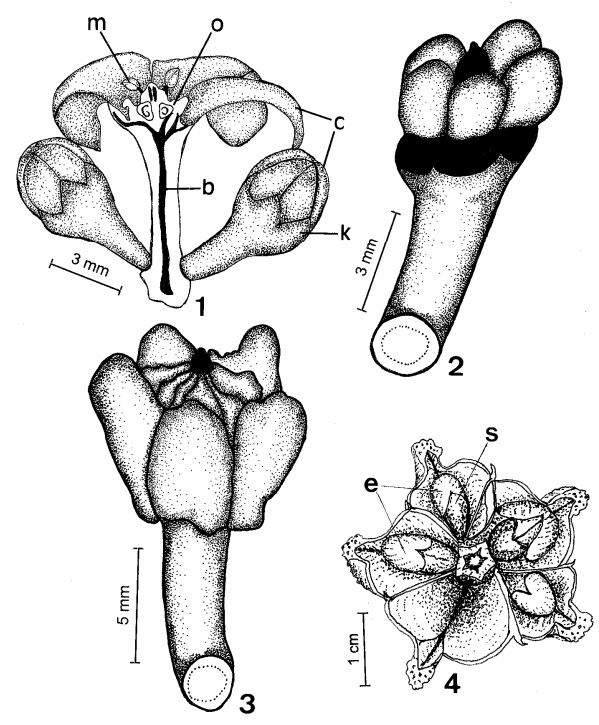

Figures 1-4 - Metrodorea nigra - Fruit in development. 1. Flower in longitudinal section and floral bud. 2-3. Young fruits. 4. Mature dehisced fruit. (b - vascular bundle; c - corolla; e endocarp; $\mathrm{k}$ - calyx; $\mathrm{m}$ - stamen; o - ovary; s - seed). 
The flower had just one red pistil with five or six carpels and locules. The carpels were united at the base, and each has a sterile projection with the secretory structures at the apex. During development, the fruit (Figs. 2 and 3) shows small splits along the line of separation between the carpels (Figs. 6, 14, 15), characterizing their incomplete union. The mature dry fruit became woody and split inside out down the dorsal sutures, liberating the seeds and the respective rigid endocarp (Figs. 4, 24). Incomplete splits occurred in the ventral sutures, but did not have direct participation in the dispersion of the seeds. Dispersion of the seeds was autochoric. The fruit was therefore capsular and coccarium.

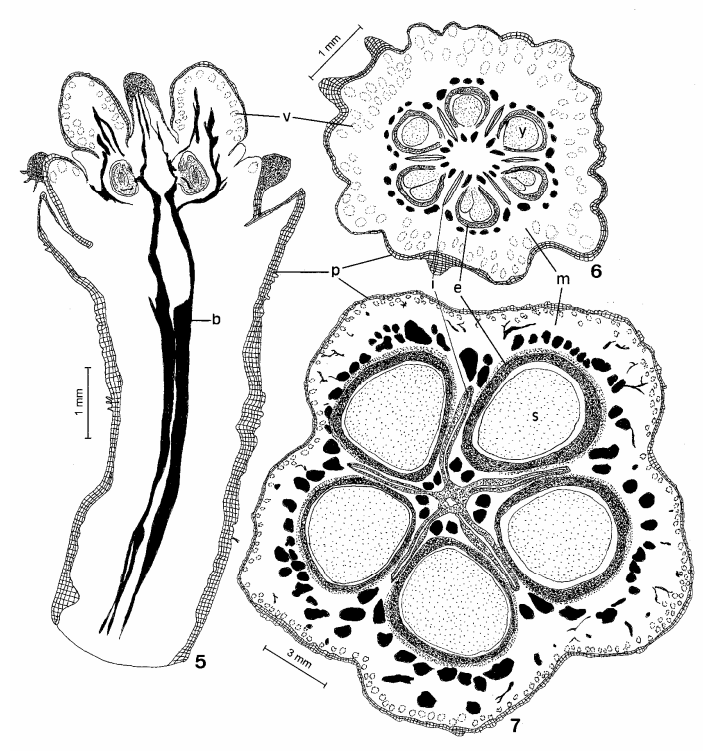

Figures 5-7 - Metrodorea nigra - Diagrams of fruit in development. 5. Young fruit in longitudinal section. 6-7. Fruit cross-section, young and mature. (b - vascular bundle; e endocarp; 1 - split; $\mathrm{m}$ - mesocarp; $\mathrm{p}$ - periderm; s - seed; v - secretory cavity; y young seed).

The ovary was almost completely constituted by nectariferous or secretory tissue (Fig. 8). The protuberances covered by the epidermis with a striate cuticle and a non-glandular trichome occurred in the upper region of the ovary. Wide secretory cavities occurred in the parenchymatic ovarian mesophyll (Fig. 8). These cavities did not occur in the basal region, in which the collateral bundles immersed in the parenchyma could be observed. The ventral epidermis (Fig. 8) was uniseriate and the cells were slightly cylindrical or tabulate. The periclinal divisions could be observed in the epidermis (Fig. 8) during preanthesis.
The pericarp originated from the wall of the ovary. The epicarp was initially represented by a simple epidermis (Fig. 10) covered by a cuticle. However, a periderm (developed very early in the fruit) was formed by the periclinal divisions that occurred in the epidermic and subepidermic cellular layers or in the deeper cellular layers of the immature mesocarp (Figs. 10 and 11). Due to the precocious installation (Figs. 5 and 6) of the periderm in the mature fruit (Fig. 7), the elimination of the epidermis and superficial mesocarp (Fig. 12) of some pericarpic regions occurred. 


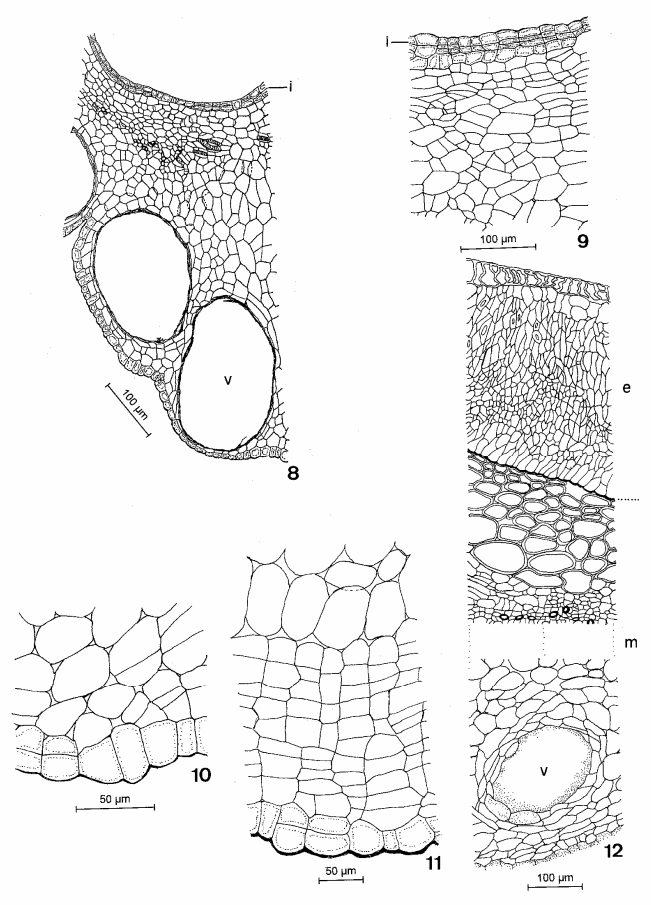

Figures 8-12 - Metrodorea nigra - Pericarp development. 8. Ovary cross-section. 9. Detail of endocarp in formation. 10-11. Detail of periderm in formation. 12. Detail of pericarp cross-section. (e - endocarp; $\mathrm{i}$ - inner or ventral epidermis in division; $\mathrm{m}$ mesocarp; $v$ - secretory cavity).

The mesocarp originated from the ovarian mesophyll. It consisted of two different regions: a) the outermost region (Fig. 12)- parenchymatic cells, idioblasts with the prismatic crystals and secretory cavities (Figs. 5 and 7) rich in the lipid content; b) the innermost region (Fig. 12)sclerenchymatic tissue originating from the subepidermic mesophyll (Fig. 9), which experienced the periclinal and anticlinal cellular divisions. A line of separation occurred in the zone of contact between the mesocarp and the endocarp of the immature fruit (Fig. 12).

The endocarp developed as a result of the periclinal divisions of the inner epidermis of the ovary in the pre-anthesis (Fig. 8). The tissue resulting from this activity (Figs. 9, 12) was differentiated into the sclereids (Figure 13), which presented diverse shapes and sizes. There were brachysclereids, osteosclereids and other irregularly-shaped sclereids in the mature endocarp (Fig. 13).

The sclereids presented thick, lignified and flat or sinuous walls (Fig. 13). The endocarp was united firmly to the funiculus of the seed (Fig. 24). The explosive ejection of the seed with the endocarp occurred in the opening of the mature fruit. This happened because the endocarp was fused to the funiculus and separated from the mesocarp. The separation from mesocarp could be seen in the early stages of the fruit development.

In the septum region of the young fruit (Fig. 14), the subepidermal cells underwent the periclinal division. The tissue formed underwent differentiation in the sclerenchyma. The epidermis in this region presented glandular trichomes (Fig. 15). The vascular bundles in the fruit were collateral and immersed in the mesocarpic parenchyma. Two ventral or marginal bundles occurred in each carpel (Figs. 6 and 7). 


\section{Seed development}

The ovules were anatropous and bitegmic (Figs. 16 and 17). Both the integuments exhibited a cuticle. The inner integument showed two or three cell layers and the outer three layers or more (Fig. 17). The ovules were crassinucellate, presenting a number of cell layers between the nucellar epidermis and the megaspore (Fig. 17). The periclinal divisions were evident in the nucellar epidermis. The ovules had long uni- or bicellular trichomes (Fig. 16) of the placental and funicular origin.

During the development of the ovule in the seed, the meristematic activity was observed in the integuments of the young seed (Figs. 19 and 20), mainly in the tegmen. In this integument, the epidermal cells showed periclinal divisions (Figs. 19 and 20) and posterior lengthening (Fig. 21). In the immature testa, already with the defined number of the cellular strata, the cells of the outer epidermis became tabulate or cubic (Fig. 21). The cells of the inner epidermis of the testa became radially elongate (Fig. 21). The nucellus also presented divisions in its more superficial cells (Figs. 19 and 20). The trichomes of funicular and placental origin were found to the young seed stage (Fig. 18).

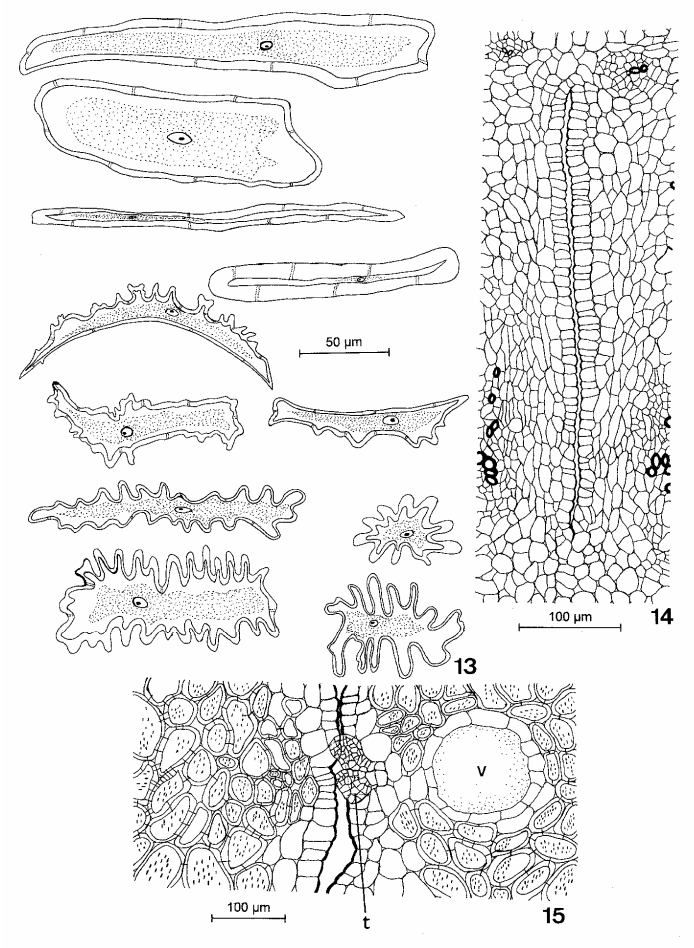

Figures 13-15 - Metrodorea nigra - Endocarp and ventral suture. 13. Sclereids. 14-15. Undifferentiated and differentiated suture. $(\mathrm{t}$ - secretory trichome; $\mathrm{v}$ - secretory cavity).

In the maturation, the seed presented deep alterations in the cellular walls of most of the tissues of the two integuments (Figs. 22 and 23). In the testa (Figs. 22 and 23) the outer epidermis presented the striate cell walls and thick periclinal outer walls. The mesophyll cells of the testa were thin-walled or became collenchymatous. The cell walls of the inner epidermis of the testa became thick and pitted. These epidermal cells were macrosclereids and commonly presented the crystals. In the tegmen (Figs. 22 and 23), the cell walls of the outer epidermis (elongate cells) and the subepidermal cellular layer became thick, lignified and pitted, i.e. fibers. The tegmic fibers 
were arranged longitudinally or transversely from one to five layers in the integument. The tegmic mesophyll stayed with the thin cell walls. The mesophyll cells of the tegmen were slightly compressed. The inner epidermis of the tegmen presented the cell walls slightly thick and pitted. The mature seed presented the nucellus reduced to the multiseriate tissue at the base of the seed. The endosperm was also reduced.

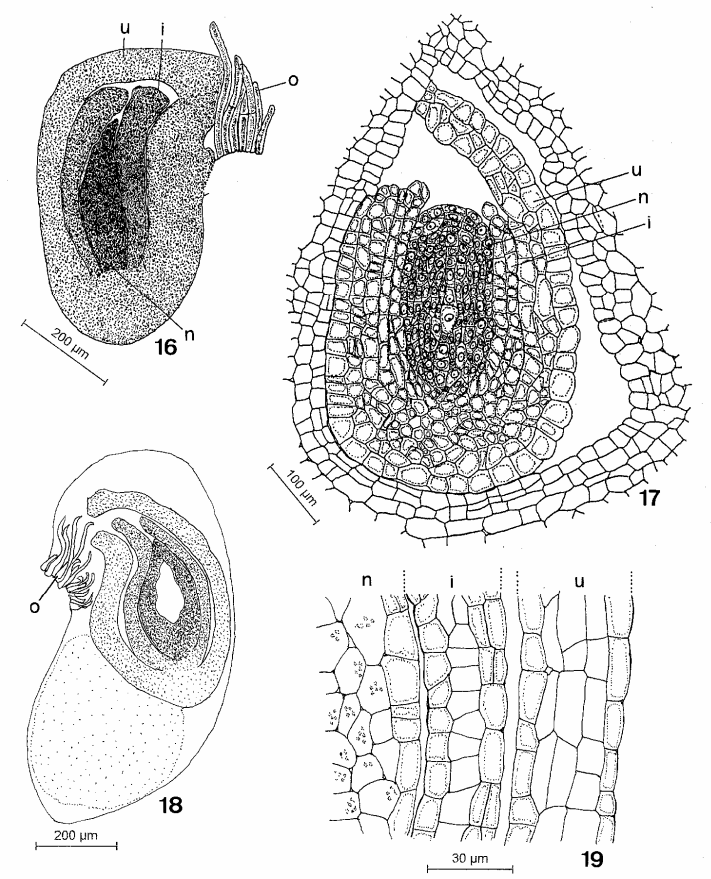

Figures 16-19 - Metrodorea nigra - Ovule and seed. 16-17. Diagram and detail of ovule in longitudinal section. 18. Diagram of undifferentiated seed in longitudinal section. 19. Detail of seed nucellus and integuments. (i - inner integument; $n$ nucellus; o - obturator; $\mathrm{u}$ - outer integument).

The mature fruit showed one or, more frequently, two seeds per locule (Fig. 24). The seed was black and larger when it occurred alone in the locule. The seed was oval, but its base could be flat (Fig. 25 ) or round depending on if it occurred isolated or with another seed in the locule. The funiculus was thick and linked to the endocarp (Fig. 24). It maintained the contact with the testa, producing a scar in the integument (Fig. 25). The embryo presented different size (Figs. 26 and 27)) according to the dimension of the seed. It was straight and possessed ample reserve cotyledons and a reduced embryonic axis (Figs. 26 and 28). The cotyledons could be asymmetric (Fig. 26) and possessed a homogeneous mesophyll with an oily parenchyma. 

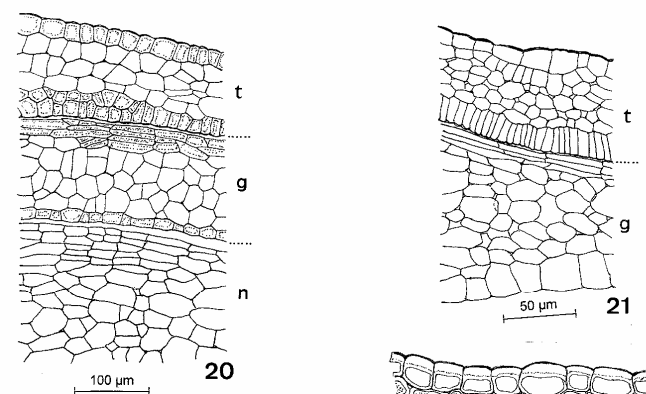

$100 \mu \mathrm{m}$
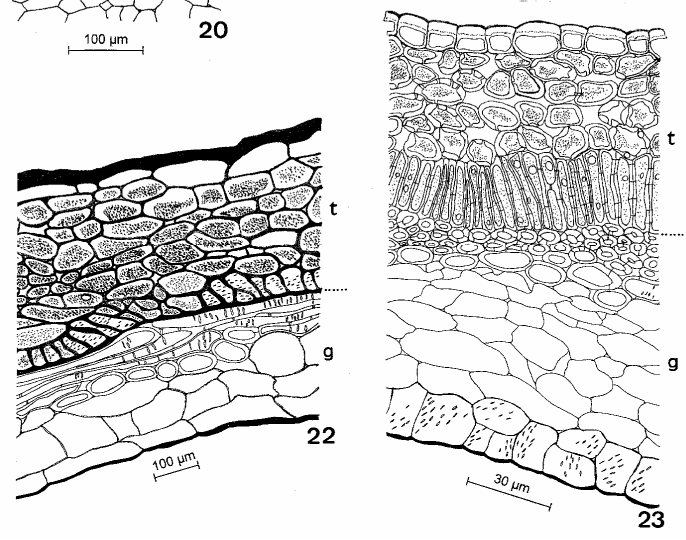

Figure 20-23 - Metrodorea nigra - Testa and tegmen in development. 20-21. Young integuments. 22-23. Mature integuments. ( $\mathrm{g}$ - tegmen; $\mathrm{n}$ - nucellus; $\mathrm{t}$ - testa).
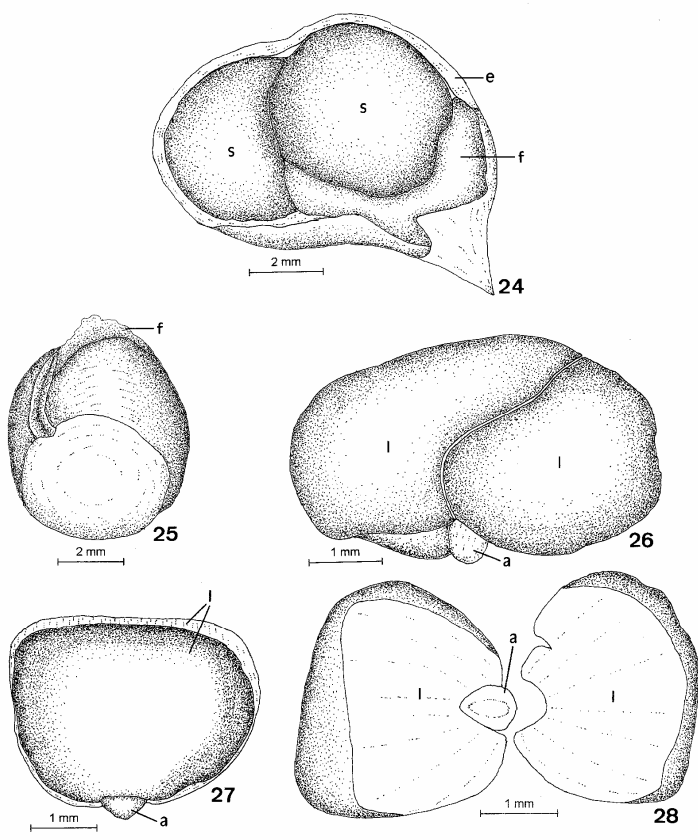

Figure 24-28 - Metrodorea nigra - Seed and embryo. 24. Two seeds covered by the endocarp. 25. Seed in general view. 26-27. Embryos. 28. Embryo showing cotyledons and axis. (a - embryo axis; e - endocarp; f - funiculus; 1 - cotyledon; $\mathrm{s}$ - seed). 


\section{DISCUSSION}

Metrodorea nigra presented capsular fruit (coccarium) (Spjut, 1994), characterized by more than one carpel with the pericarp splitting along the septa and opening dorsally. This fruit is considered technically a schizocarp, but capsular by the dehiscence (Spjut, 1994). The periderms occurred relatively rarely in the fruits, as they were generally connected with the secondary growth phenomena. The mature fruit could eventually become covered with a continuous layer of the cork, but in most cases, the periderm developed discontinuously on the pericarp or lenticels occurred scattered over the entire fruit surface (Roth, 1977). Metrodorea nigra developed a periderm on almost the whole fruit surface. Its precocious installation in the epidermic and subepidermic layers eliminated the tissue with the wide secretory cavities and hair that occurred in the wall of the ovary.

The epicarp or exocarp of the fruit of M. nigra was epidermal in the beginning of its development and peridermal at the maturity. The exocarp, which functions as the protective layer of the fruit, may consist only of the outer epidermis of the pericarp ("sensu stricto") or also subepidermal layers that are included in exocarp formation ("sensu lato") (Roth, 1977). The periderm formed in the fruit of M. nigra had its main origin in the subepidermal cells, which reinforced the opinion of the majority of modern authors that preferred the use of the term exocarp in its wide sense. The periclinal wall formation not infrequently occurred in the inner epidermis of the fruits (Roth, 1977). Great emphasis was been given to this character in Rutaceae and it is indicated as a family attribute (Hartl, 1958). In fact, the cells of the inner epidermis in $M$. nigra experience periclinal divisions starting from pre-anthesis. This multiseriate epidermis differentiates later in the sclerenchymatous endocarp.

The endocarp of $M$. nigra participated actively in the autochory process that occurred in the fruit of this species. It separated from the mesocarp, fused with the funiculus of the seed, functioned as the resistance tissue in the dehiscence mechanism of the fruit and was ejected together with the seed. The endocarp was also considered responsible for the autochory in the fruit of Esenbeckia febrifuga (Beltrati, 1991) and Pilocarpus pennatifolius
(Souza et al., 2005). The ovules of M. nigra were considered crassinucellate. However, the use of the terms crassinucellate and tenuinucellate have been generating a lot of confusion in the botanical literature. Therefore, Davis (1966) introduced the term pseudocrassinucellate for the ovules, where no the parietal cells were formed, but the apical cells of the nucellar epidermis underwent the periclinal divisions giving rise to a nucellar cap. Thus, in agreement with Souza et al. (2001), only an ontogenetic study of the nucellus of the species would be necessary to be able to affirm if the ovules were crassinucellate or pseudocrassinucellate. The ovules of $M$. nigra had long uni- or bicellular trichomes of the placental and funicular origin. These trichomes were considered by Souza et al. (2004) as an obturator. An obturator is a structure of special significance in facilitating the entry of the pollen tube into the ovule (Maheshwari, 1971) and has connection with the transmitting tissue of the style. It had been reported in other species of Rutaceae such as Ruta graveolens L., Zanthoxylum simulans Hance (Boesewinkel, 1977), Glycosmis arborea (Roxb.) D.C. (Boesewinkel, 1978) and Esenbeckia febrifuga (Beltrati, 1991).

The seed of $M$. nigra could be considered testal according Corner (1976) classification. In the testa of this species, the exotesta presents thick outer periclinal cell walls and the mesotesta can eventually be collenchymatous; but the endotesta can be considered the principal mechanical layer. Therefore, the seed of $M$. nigra could be classified as the endotestal. This classification differed from that presented for other Rutaceae species (Corner, 1976), which only presented the exotestal or mesotestal seeds.

It had been reported the exotegminal fibers in the seeds of several families, but not in Rutaceae (Dahlgren, 1991). However, M. nigra presented the fibers in the outer epidermis of the tegmen. Conditions were selected that seem to be of particular phylogenetic significance (Dahlgren, 1991), referring to the groups of "exotegminal" families (Corner, 1976). In one group (the second), non-multiple exotegminal fibers were combined with a thick-walled exotestal layer and crystals in the endotestal layer, as occurred in M. nigra. This group consisted only of Meliaceae of the order Rutales. 


\section{RESUMO}

O pericarpo e a semente em desenvolvimento de Metrodorea nigra foram investigados estruturalmente. Flores e frutos em diferentes estágios de maturação foram fixados em FAA 50 e secionados transversal e longitudinalmente, conforme técnicas usuais. $\mathrm{O}$ epicarpo diferenciado é representado pela periderme de origem subepidérmica. $\mathrm{O}$ mesocarpo é parenquimático. $\mathrm{O}$ endocarpo é esclerenquimático e se origina da ação meristemática da epiderme interna do ovário. A semente endostestal provém de óvulo anátropo, bitegumentado e crassinucelado. $\mathrm{O}$ nucelo e o endosperma ocorrem em pequena quantidade na semente madura. $\mathrm{O}$ embrião é reto com espessos cotilédones. A semente e o endocarpo são dispersos por processo autocórico. O fruto é capsular e coccarium.

\section{REFERENCES}

Barroso, G. M., Morim, M. P., Peixoto, A. L. and Ichaso, C. L. F. (1999), Frutos e sementes: morfologia aplicada à sistemática de dicotiledôneas. Viçosa: Editora UFV. pp. 299-306.

Beltrati, C. M. (1991), Estudo morfo-anatômico das sementes e plântulas de Esenbeckia febrifuga (St. Hil.) A. Juss. ex Mart. (Rutaceae). Naturalia, 16, 161-169.

Berlyn, P. G. and Miksche, J. P. (1976), Botanical microtechnique and cytochemistry. Ames: The Iowa State University Press. pp. 240-309.

Boesewinkel, F. D. (1977), Development of ovule and testa in Rutaceae. I-Ruta, Zanthoxylum and Skimmia. Acta Bot. Neerl., 26, 193-211.

Boesewinkel, F. D. (1978), Development of ovule and testa in Rutaceae. III - Some representatives of the Aurantioidae. Acta Bot. Neerl., 27, 341-354.

Boesewinkel, F. D. and Bouman, F. (1978), Development of ovule and testa in Rutaceae. II - The unitegmic and pachychalazal seed of Glycosmis arborea (Roxb.) D. C. Acta Bot. Neerl., 27, 69-78.

Corner, E. J. H. (1976), The seeds of dicotyledons. Cambridge: Cambridge University Press, vol. 1 and 2. pp. 232-237 and 404-423.
Cronquist, A. (1981), An integrated system of classification of flowering plants. New York: Columbia University Press. pp. 815-817.

Dahlgren, G. (1991), Steps toward a natural system of the dicotyledons: embryological characters. Aliso, 13, 107-165.

Davis, G. L. (1966), Systematic embryology of the angiosperms. New York: John Wiley and Sons.

Dnyansagar, V.R. (1958), Embryological studies in the Leguminosae VIII. Acacia auriculaeformis A Cunn., Adenanthera pavonina Linn., Calliandra grandiflora Benth. Lloydia, 21, 1-25.

Hartl, D. (1958), Struktur und Herkunft des Endokarps der Rutaceen. Beitr. Biol., Pfl. 34, 35-49.

Johansen, D. A. (1940), Plant microtechnique. New York: McGraw-Hill Book. pp. 27-203.

Lorenzi, H. (1992), Árvores brasileiras - manual de identificação e cultivo de plantas arbóreas do Brasil. Nova Odessa: Editora Plantarum, vol. 1. p. 309.

Maheshwari, P. (1971), An introduction to the embryology of angiosperms. New Delhi: Tata McGraw-Hill Publishing Company. pp. 185-187.

Roth, I. (1977), Fruits of angiosperms. In-Encyclopedia of Plant Anatomy, eds. K. Linsbauer, F. G. Tischler and A. Pascher, Gebrüder Borntraeger, Berlin, vol. 10, pp 9-48.

Souza, A.; Mourão, K. S. M. and Souza, L. A. (2005), Morfologia e anatomia do fruto e da semente em desenvolvimento de Pilocarpus pennatifolius Lem. (Rutaceae). Rev. Brasil. Bot., 28: (4), 745-754.

Souza, L. A.; Moscheta, I. S.; Mourão, K. S. M. and Silvério, A. (2001), Morphology and anatomy of the flowers of Trichilia catigua A. Juss., T. elegans A. Juss. and T. pallida Sw. (Meliaceae). Arch. Biol. Tech., 44: (4), 383-394.

Souza, L. A.; Moscheta, I. S.; Mourão, K. S. M. and Rosa, S. M. (2004), Morphology and anatomy of the flower and anthesis of Metrodorea nigra St. Hill. (Rutaceae). Braz. Arch. Biol. Tech., 47: (1), 107-112.

Spjut, R. W. (1994), A systematic treatment of fruit types. Mem. New York Bot. Gard., 70, 1-182.
Received: June 19, 2006; Revised: October 17, 2007; Accepted: March 13, 2008. 
PÁGINA

EM

BRANCO 